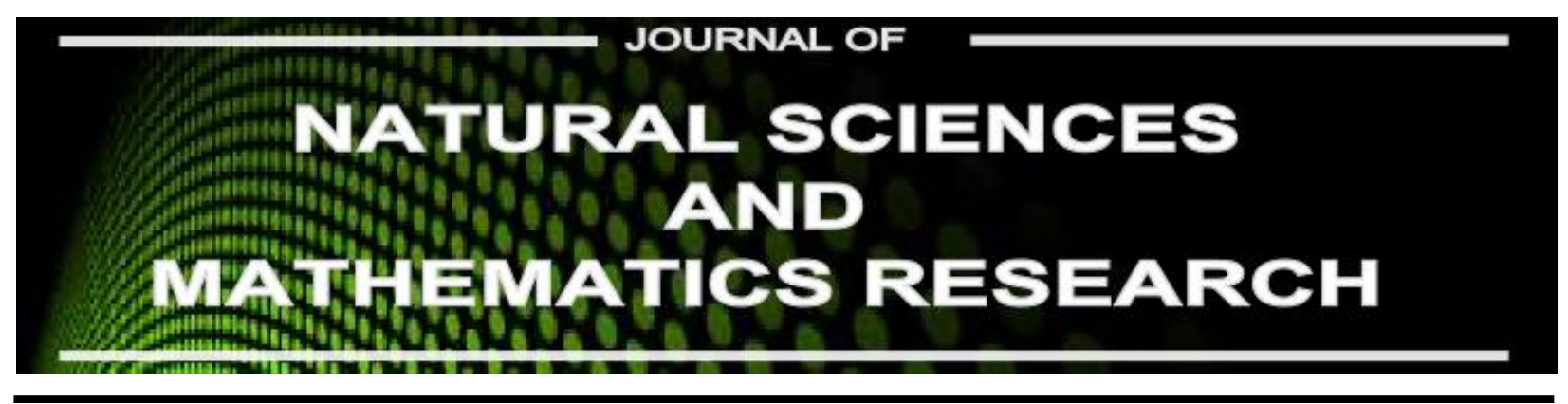

Available online at http://journal.walisongo.ac.id/index.php/jnsmr

\title{
In Vitro Inhibition Capacity in Ca Oxalate Formation by Lemon (Citrus Lemon) Juice
}

\author{
Endang Tri Wahyuni Maharani'1, Jatmiko Susilo², Arifiani Agustin Amalia ${ }^{3}$ \\ ${ }^{1}$ Diploma Program of Health Analyst Faculty of Nursing and Health Semarang Muhammadiyah University, \\ Central Java, Indonesia \\ ${ }^{2}$ Undergraduate Program of Pharmacy STIKES Ngudi Waluyo Semarang \\ ${ }^{3}$ Diploma Program of Health Analyst Semarang Muhammadiyah University
}

\begin{abstract}
s
Corresponding author: This research aims to determine the inhibition capacity of lemon juice (Citrus endangtm@gmail.com Recived: 3 Nopember 2015, Revised : 25 November 2015 Accepted: 20 December 2015. lemon) in the formation of calcium oxalate in a variety of concentrations of $5 \%$, $7.5 \%, 10 \%$ which is then compared to pure citric acid. Lemon juice contains citric acid that can inhibit calcium oxalate's formation. Inhibitory activity found in lemon juice is examined by observing its inhibition capacity towards the formation of calcium oxalate crystal. At the end of the treatment process the turbidity level is compared to citric acid acting as an inhibitor in the formation of calcium oxalate and then the percentage of the inhibition capacity is calculated. Result of the study shows that the optimum concentration of the lemon juice (Citrus lemon) and citric acid is 10\%. The inhibition capacities in calcium oxalate formation by lemon juice with concentration variations of $5 \%, 7.5 \%, 10 \%$ are $47.06 \%, 73.68 \%, 94.19 \%$ and by citric acid with concentration variations of $5 \%$, $7.5 \%, 10 \%$ are $29.90 \%, 30.85 \%, 42.30 \%$. It can be concluded that the higher the concentration of lemon juice and citric acid used the higher the inhibition capacity of calcium oxalate. Based on the inhibition capacity percentage, lemon juice is more effective in inhibiting the formation of calcium oxalate compared to citric acid and it can function as an alternative to prevent the formation of kidney stone. (C) 2015 JNSMR UIN Walisongo. All rights reserved
\end{abstract}

Key words: Inhibition Capacity; Lemon Juice,; Citric Acid.

\section{Introduction}

Kidney stone is small solid materials formed in the kidney as a result of deposition happening in the urine moving down to ureter.
The stone can cause a blockage in the urethra resulting in pain and trouble in urinating. Kidney stone contains either one or a combination of both calcium oxalate and calcium phosphate [1]. 
Kidney stone is formed because of crystalized urine, kidney acidity abnormality, and the decrease in the crystal forming inhibition in healthy adult. Urine $\mathrm{pH}$ ranges between 4,5-8,0 and average urine $\mathrm{pH}$ is 6,0. Acidic urine increases the likelihood of forming calcium stone and uric acid, while base urine increases the likelihood of forming sutruvit stone. Thus, checking the acidity of urine is crucial [2]. Normally the formation of kidney stone calcium is inhibited by flavonoid, potassium, magnesium, and citric acid [1].

Lemon (Cytrus lemon) is a fruit commonly grown in Indonesia. It has low glucose level and tastes sour because it contains citric acid. The level of sourness in the fruit is the result of the high citric acid level. Citric acid is an organic compound in a form of crystal that is colorless, odorless, sour, and easily dissolved in water or alcohol. The citric acid level in lemon juice is $48,6 \mathrm{~g} / \mathrm{kg}$. Citric acid is beneficial to prevent the forming of kidney stone. Citric acid in oranges is known to be able to break down several substances namely sulfate, phosphate and natrium that can potentially form kidney stone causing kidney faliure [3].

Kidney stone or calcium oxalate is formed because of hipositraturia factor in the urine, a pocess in which citric acid reacting with calcium forming calcium citrate that blocks the bonding between calcium and oxalate or phosphate. It is possible because calcium citrate is more easily dissolved compared to calcium oxalate. Therefore, citric can function as inhibitor to the forming of calcium stone. The chemical reaction is as follows:

Calcium oxalate + Citric acid $\rightarrow \quad$ Calciun Citrate + Oxalic acid

Several studies have been conducted upon the dissolvance effect of kidney stone, especially calcium stone, by using traditional herbs namely: radish (Rhapanus sativus), leafflower (Phyllanthus niruri, L.), sow thistle
(Sonchus arvensis), kecibeling leaf (Strobilanthes crispus), yardlong bean (Vigna sinensisENDL.). From the study, it is proven that mentioned herbs has the ability to dissolve kidney stone calcium $[4,5,6]$. Nevertheless, there has been no research conducted to study the dissolvance level of kidney stone by lemon juice eventhough lemon is commonly found in our society. Based on the above reason, a study on the in vitro inhibition capacity in calcium oxalate formation by lemon juice is conducted.

\section{Experiments Procedure}

The study is using experimental, comparatian and factorial researches, a research method conducted with the purpose of testing a certain research object to compare the concentration of lemon juice and citric acid. Object of the study is lemon juice squeezed in a juicer. It is used to inhibit the formation of $\mathrm{Ca}$ oxalate with concentration variations of $5 \% ; 7,5 \% ; 10 \%$, and as comparator, citric acid is used with the concentration variations of $5 \% ; 7,5 \% ; 10 \%$. Each sample treatment is repeated five times.

\section{Result and Discussion}

Concentrated lemon juice is used on preliminary test in order to determine the percentage of concentration that will be used in the study and to test the inhibition capacity in the formation of calcium oxalate. On the preliminiray test, the concentration of lemon juice varies from $5 \%, 7,5 \%, 10 \%, 15 \%$ to $25 \%$. Positive control is also applied in the preliminary test in a form of citric acid with the same concentration level as the lemon juice. These are the standard concentration used to test the inhibition capacity in the formation of calcium oxalate. Negative control is also applied in a form of not adding lemon juice or citric acid. 
Tabel 1. Turbidity in calcium oxalate formation by lemon juice and citric acid.

\begin{tabular}{|c|c|c|c|c|c|c|c|c|c|c|}
\hline \multicolumn{11}{|c|}{ Turbidity in Ca Oxalate Formation (NTU) } \\
\hline \multirow[t]{2}{*}{ Control } & \multicolumn{5}{|c|}{ Lemon Juice } & \multicolumn{5}{|c|}{$\begin{array}{l}\text { Citric Acid } \\
(100 \% \text { equals to } 48,6 \% \text { citric in } 100 \mathrm{~g} \\
\text { lemon) }\end{array}$} \\
\hline & $5 \%$ & $7,5 \%$ & $10 \%$ & $15 \%$ & $25 \%$ & $5 \%$ & $7,5 \%$ & $10 \%$ & $15 \%$ & $25 \%$ \\
\hline 290 & 153 & 76,6 & 17 & 63,6 & -57 & 211 & 208,8 & 204,8 & 177,2 & 233,2 \\
\hline
\end{tabular}

Result of the preliminary test is to find te lemon juice concentration that has the closest outcome to citric acid acting as the positive control. Based on the result shown in Table 1, the inhibition capacity of $5 \%$ concentration reaches the percentage capacity of $5 \%$ citric acid, meaning that $5 \%$ concentration of lemon juice can inhibit the formation of calcium oxalate, therefore $5 \%$ concentration is used as control to determine the concntration applied in the research test. The $25 \%$ concentration shows negative result which is most likely to be invalid because the device might be unable to detect the turbidity, thus this concentration level cannot be applied to be the control in the research test. The applicable concentration levels in this research are 5\%,7,5\% and 10\%. Solution of $\mathrm{CaCl}_{2}$ and $\mathrm{H}_{2} \mathrm{C}_{2} \mathrm{O}_{4}$ are devided into 7 groups and given different treatments. The first group is not given the lemon juice or citric acid on the $\mathrm{CaCl}_{2}$ and $\mathrm{H}_{2} \mathrm{C}_{2} \mathrm{O}_{4}$ solutions to act as preliminary turbidity value. The second to fourth groups are given lemon juice with concentration levels of $5 \%, 7,5 \%$, and $10 \%$. The fifth to sevent groups act as the positive control, $\mathrm{i}$ which the fith group is given citric acid with concentration levels of $5 \%, 7,5 \%$, and $10 \%$.

Result in Table 2 shows that the first group that is not given lemon juice or citric acid has a high turbidity value because there is a reaction between $\mathrm{CaCl}_{2}$ and $\mathrm{H}_{2} \mathrm{C}_{2} \mathrm{O}_{4}$ resulting in the formation of calcium oxalate shown by the turbidity. It is confirmed that calcium oxalate used in the study is formed well. Citric acid used in this study acting as the positive control is an active substance proven to be effective in dissolving calcium oxalate resulting in the inhibition of kidney stone formation.

Table 2. Estimation on lemon juice and citric acid concentration towards the formation of calcium oxalate

\begin{tabular}{|c|c|c|c|c|c|c|c|}
\hline \multirow{4}{*}{ Treatment } & \multicolumn{7}{|c|}{ Turbidity of calcium oxalate (NTU) } \\
\hline & Preliminar Turbidity & \multicolumn{6}{|c|}{ Final Turbidity } \\
\hline & \multirow[t]{2}{*}{ Control - } & \multicolumn{3}{|c|}{ Lemon Juice } & \multicolumn{3}{|c|}{$\begin{array}{l}\text { Citric Acid (control }+ \text { ) } \\
(100 \% \text { equals to } 48,6 \% \text { citric in } \\
100 \text { g lemon) }\end{array}$} \\
\hline & & $5 \%$ & $7,5 \%$ & $10 \%$ & $5 \%$ & $7,5 \%$ & $10 \%$ \\
\hline $\mathrm{I}$ & \multirow{5}{*}{290} & 149 & 69 & 20 & $188^{*}$ & $243,6^{*}$ & 171 \\
\hline II & & 153 & 62 & 19 & 204,5 & $252,7^{*}$ & 170 \\
\hline III & & 164 & 113 & 20 & 203,7 & 201,7 & 165 \\
\hline IV & & 154 & 72 & 6 & 200,5 & $170^{*}$ & 169 \\
\hline $\mathrm{V}$ & & 147 & 65 & 20 & 203,7 & 199 & 161 \\
\hline Average & 290 & 153,4 & 76,6 & 17 & 203,1 & 200,35 & 167,2 \\
\hline
\end{tabular}

*data unused 
Result in Table 3 shows that lemon juice has inhibiting effect towards the formation of calcium oxalate. This fact is coherent with the preliminary hypothesis stating that lemon juice concentration affect the formation of calcium oxalate. The inhibition capacity in calcium oxalate formation is shown in the declining of the turbidity value of $\mathrm{CaCl}_{2}$ and $\mathrm{H}_{2} \mathrm{C}_{2} \mathrm{O}_{4}$ solution before and after adding the lemon juice by using the optimum time already known. Result shows that the higher the lemon juice concentration, the bigger the average percentage of calcium oxalate inhibition. It also shows that the higer the lemon juice concentration, the higher the inhibition of calcium oxalate formation. One way ANOVA test is used to acknowledge wether there are differences in the average percentage level of inhibition in the seven groups given the treatment. The result is significant, with $\alpha<0,05$ showing that lemon juice and citric acid has different effects on every concentration level in inhibiting the formation of calcium oxalate. Tukey test shows that lemon juice and citric acid in concentration level of $5 \%$ has a significant difference of 0,000 so that $\alpha<0,05$. Concentration levels of $7,5 \%$ and $10 \%$ also has significance value of 0,000 so that the concentration of the two variable groups of lemon juice and citric acid has a signifcant difference towards the effectiveness of inhibition capacity in the calcium oxalate formation.

Table 3. Percentage of inhibition capacity in calcium oxalate formation by lemon juice and citric acid.

\begin{tabular}{|c|c|c|c|c|c|c|}
\hline \multirow{3}{*}{ Repetition } & \multicolumn{6}{|c|}{ Inhibition Capacity in Calciu oxalate Formation (\%) } \\
\hline & \multicolumn{3}{|l|}{ Lemon Juice } & \multicolumn{3}{|c|}{$\begin{array}{l}\text { Citric Acid } \\
(100 \% \text { equals to } 48,6 \% \text { citric in } \\
\text { lemon) }\end{array}$} \\
\hline & $5 \%$ & $7,5 \%$ & $10 \%$ & $5 \%$ & $7,5 \%$ & $10 \%$ \\
\hline I & 48,6 & 76,2 & 93,1 & $35,1^{*}$ & $16,31^{*}$ & 41,0 \\
\hline II & 47,2 & 78,6 & 93,4 & 29,4 & $12,8^{*}$ & 41,3 \\
\hline III & 43,4 & 61,0 & 93,1 & 29,7 & 30,4 & 43,1 \\
\hline IV & 46,8 & 75,1 & 97,9 & 30,8 & $41,3^{*}$ & 41,7 \\
\hline $\mathrm{V}$ & 49,3 & 77,5 & 93,1 & 29,7 & 31,3 & 44,4 \\
\hline Average & $47,060,97$ & $73,68 \pm 1,20$ & $94,12 \pm 0,11$ & $29,9 \pm 1,20$ & $30,85 \pm 0,45$ & $42,3 \pm 2,75$ \\
\hline
\end{tabular}

$*$ data unused

Based on Table 3, lemon juice has more effective inhibition capacity in calcium oxalate formation compared to citric acid. The study shows that lemon juice (Citrus lemon) can be used as an alternative solution to cure kidney stone. Further study to know the toxixity level on certain concentration levels using different methods is necessary. The turbidity is affected not only by calcium oxalate formation but also by the turbid lemon juice. It can be concluded that turbidimetry method is incompatible to test the lemon juice because the turbidity value is not purely derived from the reaction formed.

\section{Conclusion}

The result of the study, it can be concluded that: the inhibition capacities in the formation of $\mathrm{Ca}$ oxalate in a variety of concentrations of $5 \%, 7.5 \%, 10 \% 5 \%, 7,5 \%$, $10 \%$ are $47,06 \%, 73,68 \%, 94.19 \%$ and by citric acid with concentration variations of $5 \%, 7.5 \%, 10 \%$ are $29,90 \%, 30,85 \%, 42,30$ $\%$. Lemon juice is more effective in inhibiting the formation of $\mathrm{Ca}$ oxalate compared to citric acid. 


\section{Acknowledgment}

The author wish to Program of Health Analyst Faculty of Nursing and Health Semarang Muhammadiyah University, Program of Pharmacy STIKES Ngudi Waluyo Semarang, for support in this research.

\section{References}

[1] A.W. Sundoyo and B. Setiyohadi, Buku Ajar Penyakit Dalam, $4^{\text {th }}$ Edition. PP Departemen ilmu penyakit dalam. Jakarta, 2006.

[2] J.B. Cahyono and B. Suharjo. Hepatitis A. Edisi 1. Yogyakarta: Kanisius, 2009.
[3] M. Astawan, A.L. Kasih, Khasiat Warnawarni Makanan. PT Gramedia Pustaka Utama, member of IKAPI, Jakarta, 2008.

[4] Suparmi. Makna Pendampingan Spiritual pada Asuhan Keperawatan Pasien Preoperasi di PK Sint. Corolus Jakarta. Thesis. Universitas Indonesia Jakarta, 2008.

[5] Purwaningrum dan kadarsih, Efek Sari Lobak (Raphanus sativusL.) Terhadap Kelarutan Batu Ginjal Kalsium Secara In Vitro. Skripsi. Fakultas Farmasi Universitas Indonesia, Jakarta , 2005.

[6] Kurnia, E. dkk., Penelitian Daya Larut Daun Spesies-spesies Sonchus dan Empat Jenis Tumbuhan kejibeling Terhadap Beberapa Batu Kalsium. Prosiding Simposium Tanaman Obat I. Bagian Farmakologi. Fakultas Kedokteran IPB, Bogor, 1975. 